\title{
ヒト微量血からの新しい好中球分離法の検討
}

\author{
工藤 恵美子*1, 小松尚*1, 中路 重 之*1, \\ 菅 原 和夫*1, 熊 汇隆*2
}

*1弘前大学医学部衛生学教室, *2国立公衆衛生院労衝衛生学部

\section{Investigation of a New Method for Separation of Neutrophils from a Small Volume of Human Blood}

\author{
Emiko Kudoh*1, Takashi Komatu*1, Shigeyuki Nakaji*1, \\ Kazuo Sugawara*1 and Takashi Kumae*2 \\ *1Department of Hygiene, Hirosaki University School of Medicine, Hirosaki \\ ${ }^{* 2}$ Department of Industrial Health, the Institute of Public Health, Tokyo
}

\begin{abstract}
We have already reported a neutrophil separation method for the multiple simultaneous measurement of neutrophil chemiluminescence. However, when the reported separation method was used, at least $4 \mathrm{ml}$ of venous blood was needed to collect enough neutrophils for chemiluminescent measurement. Because of this blood volume, there is a limitation on applications of the multiple simultaneous method for neonates, infants, and in some clinical situations.

To expand the application of this neutrophil chemiluminescence measurment into clinical and health science areas, we have developed a new method for separation of neutrophils from a relatively small amount of blood $(500 \mu \mathrm{l})$. In addition, the influences of remaining red blood cells and hemoglobin levels in the neutrophil fraction on the chemiluminescence were examined to determine the necessity for elimination procedures.

The new separation method used a capillary tube (length, $130 \mathrm{~mm}$; outside diameter, $5 \mathrm{~mm}$; thickness, $0.8 \mathrm{~mm}$ ) with density gradient reagents (Histopaque 1077 and 1119). After centrif ugal separation (500g, 30min), the neutrophil fraction was isolated with $93.1 \pm 4.7 \%$ purity and $60.6 \pm 11.1 \%$ yield. This purity and yield were comparable to or better than those with the previously reported method, while levels of remaining red blood cells and hemoglobin were about the same. Remaining red blood cells and hemoglobin in the neutrophil fraction acted on the chemiluminescence as a quencher. For the correct estimation of neutrophil chemiluminescence, elimination of remaining red blood cells and hemoglobin in the neutrophil fraction is necessary.

This new neutrophil separation method is a very useful method, especially for cases in which available blood amounts are limited.
\end{abstract}

Key words : Neutrophil separation method, Small volume of blood, Chemiluminescence, Quencher of CL

好中球分離法, 微量血, 化学発光, クエンチャー

\section{緒言}

近年，白血球が異物を取込む際に，活性酸素種を放出 することが判明し，この活性酸素種が励起状態から基底 状態にもどる際に発光することを利用して好中球機能を
評価する方法を，1972年Allen らが報告した1)。さらに， ルミノールを添加し, 発光量を增加させる方法である luminol-dependent chemiluminescence (以下LDCLと略) が開発されで), AndersonらによってATP-spectrophotometer による簡便な測定法が確立された ${ }^{5)}$ 。熊江らは， 
それを応用して好中球chemiluminescence (以下CLと略) の多検体同時測定法を考案し6), 多方面から好中球CL を検討し報告してきているて 9)。非特異的感染防御機構 をなす好中球機能の低下は, 慢性肉芽腫症, Chediak東症候群等の疾患を引き起こすことで知られている10)。 また, 新生児期の細菌感染症の重篤化の一因としても,

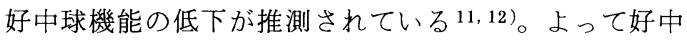
球機能を測定することは, 細菌感染症の予防及び予後の 予測の上で重要な意味をなすと考えられる。しかし, 好 中球機能を測定するのに十分な量の好中球を確保するた めには, ある程度の採血量を必要とし, 新生児期のよう に採血量に制限のある場合の好中球機能の評価は困難で, また集団健診等のスクリーニング検査として活用するこ ともできなかった。

そこで我々は, capillary tubeを用いて, 少量の採血 量で好中球を高純度かつ高収率で分離する方法を開発し， 集団健診のスクリーニング検査などに活用できるように することを目的として，研究を行っている。本報では， この新しい好中球分離法で分離した好中球を用いてLDCL を測定し，分離方法間の差異を従来法と比較検討した。 さらに, 分離後の好中球浮遊液中に残存する赤血球が, LDCLに及ぼす影響についても検討したので報告する。

\section{実験方法}

\section{1. 対 象}

一般血清生化学検査20項目 (総蛋白, アルブミン, ナ トリウム, カリウム, クロール, 尿素窒素, クレアチニ ン, カルシウム, リン, 尿酸, トランスアミナーゼ(GOT, GPT), アルカリホスファターゼ, コリンエステラーゼ, 乳酸脱水素酵素, $\gamma$-グルタミールトランスペプチダー ゼ, 総ビリルビン, 直接ビリルビン, 総コレステロール, 中性脂肪)において異常を認めず，何らの自覚症状も有 さない健康で正常と思われる成人(以下健康正常成人と 略)を対象とした。対象者は実験の内容を理解し, 採血 に自発的に協力を申し出たものである。好中球分離法を 検討する実験においては，25歳から 34 歳をで(平均 28.4 \pm 2.2 歳)の健康正常成人 10 人を対象者とした。また, 赤 血球の混入がLDCLに与学る影響を検討する実験も, 健 康正常成人 10 人 $(21$ 歳から 34 歳, 平均 $25.5 \pm 3.9$ 歳)を対 象者とした。

\section{2. 好中球分離試薬}

好中球分離試薬としてHistopaque-1077, 1119 (Sigma 社), Mono-Poly Resolving Medium（以下M-PRM々 略，フロウラボラトリーズ社)を用いた。Histopaque-1077， 1119は, Ficoll とsodium diatrizoateを比重1.077およ び1.119になるように混合した溶液である。通常は, buffer 等で 2 倍に希釈した全血と同量ずつ重層して用いる $\left.{ }^{13}, 14\right) 。$ 一方のM-PRMは, FicollとHypaqueを比重1.114にな るように混合した溶液で，通常は全血を希釈せずに，こ の分離液と体積比で $1: 1$ の割合で重層して用いる ${ }^{15,16) 。 ~}$

\section{3 . Capillary tube の選択}

通常の遠心器に適応できる長さと硝子管のJIS規格を 考慮して, a ) 外径 $2.7 \mathrm{~mm}$ - 肉厚 $0.35 \mathrm{~mm} \cdot$ 長さ $120 \mathrm{~mm}$, b) 外径 $4 \mathrm{~mm}$ - 肉厚 $0.8 \mathrm{~mm}$-長さ $130 \mathrm{~mm}, c$ ) 外径 $5 \mathrm{~mm}$ - 肉厚 $0.8 \mathrm{~mm}$ ・長さ $130 \mathrm{~mm}$, および $\mathrm{d}$ ) 外径 $6 \mathrm{~mm}$ ・肉 厚 $1.0 \mathrm{~mm}$ ・長さ $120 \mathrm{~mm}$ の計 4 種類のcapillary tube 用意し, それぞれのtubeによる好中球分離能を比較検 討した。また，好中球のガラス壁面への接着を防ぐ目的 で, シリコフィルム(半井化学薬品株式会社)によるcapillary tubeのシリコンコーティングも試みた。

\section{4. 好中球分離法}

健康成人の肘正中皮静脈から採血し, 血液と同量のへ パリン加Hanks' balanced salt solution (以下HBSSと略, GIBCO社)に加えて 2 倍希釈全血とした後に, Table 1に 記す 4 通りの重層法を行った。

$\mathrm{A}$ 法 : 従来法。外径 $16.0 \mathrm{~mm}$, 肉厚 $0.9 \mathrm{~mm}$, 長さ $100 \mathrm{~mm}$ のBorosilicate Glass Tubeを用い, Histopaque1119 と1077を $4 \mathrm{ml}$ ずつ重層し，その上に同量 ( 4 $\mathrm{ml})$ の希釈全血を重層した。

$B$ 法: 外径 $10.0 \mathrm{~mm}$, 肉厚 $0.6 \mathrm{~mm}$, 長さ $75 \mathrm{~mm}$ のBorosilicate Glass Tube にHistopaque-1119と1077, 希釈全血 をそれぞれ $1 \mathrm{ml}$ ずつ重層した。

Table 1 Density-gradient method

\begin{tabular}{|c|c|c|c|c|c|c|c|c|}
\hline & \multirow{2}{*}{$\begin{array}{l}\text { blood volume } \\
(\mathrm{ml})\end{array}$} & \multicolumn{4}{|c|}{ Tube } & \multicolumn{3}{|c|}{ Isolation medium } \\
\hline & & ext.d.(mm) & leng. $(\mathrm{mm})$ & thick. (mm) & number & & density & volume (ml) \\
\hline $\mathrm{A}$ & 2.0 & 16.0 & 100.0 & 0.9 & 1 & \multirow{3}{*}{$\begin{array}{c}\text { Histopaque }-1077 \\
+ \\
\text { Histopaque }-1119\end{array}$} & \multirow{2}{*}{1.077} & each 4.0 \\
\hline B & 0.5 & 10.0 & 75.0 & 0.6 & 1 & & & each 1.0 \\
\hline $\mathrm{C}$ & 0.5 & 5.0 & 130.0 & 0.8 & 3 & & 1.119 & each 1.0 \\
\hline $\mathrm{D}$ & 0.5 & 5.0 & 130.0 & 0.8 & 2 & M-PRM & 1.114 & 1.0 \\
\hline
\end{tabular}

ext.d.: external diameter, leng.: length, thick.: thickness, M-PRM: Mono-Poly Resolving Medium 
C法: 外径 $5.0 \mathrm{~mm}$, 肉厚 $0.8 \mathrm{~mm}$, 長さ $130 \mathrm{~mm}$ のCapillary Tubeを用い, Histopaque-1119と1077, 希釈全 血をそれぞれ約 $330 \mu 1$ ずつ重層した。同じ物を 3 本作製し, 合計 $1 \mathrm{ml}$ の希釈全血を好中球分離に 使用した。

D法：C法と同様のCapillary Tubeに, M-PRMと希釈 全血をそれぞれ $500 \mu \mathrm{l}$ ずつ重層した。同じ物を 2 本作製し，合計 $1 \mathrm{ml}$ の希釈全血を好中球分離に 使用した。

$\mathrm{A} \sim \mathrm{D}$ 法でそれぞれ重層したものを，500Gで30分間 遠心分離して好中球分画を取り出した。さらに, HBSS で 2 回洗浄した後に, 混在している赤血球を $0.2 \% \mathrm{NaCl}$ を用いる溶血操作で除去した。

各好中球分離法における好中球の選択性及び収率を比 較検討するために, 各対象者の全血及びそれぞれの分離 法毎の好中球分画の塗抹標本を作製し, Giemsa 染色を 行って白血球百分率を算定した。

また, 溶血操作後も好中球分画中に残存する赤血球数 と血色素(Hemoglobin; 以下Hb と略)濃度を自動血球計 数装置Sysmex F-300 (東亜医用電子株式会社製)を用い て測定し，Hb 濃度として表示した。

\section{5. 好中球LDCL測定の基本操作}

すでに報告6)したように，被貪食粒子として，基準血 清でオプソニン化したZymosanを用いた。

好中球数は, 自動血球計数装置Sysmex F-300を用い て3.0 $\times 10^{6} \mathrm{cells} / \mathrm{ml}$ に調製し，LDCLの測定に用いた。 Lumiphotometer TD-4000にコンピューター(NEC PC9801 UV)を接続して, 熊江らの報告した好中球CL多検体同 時測定法 ${ }^{6)}$ に準じて行った。

測定值は，すでに報告6)したように，それぞれ各検体 の最大発光時間(Peak Time ; 以下PTと略) と最大発光量 (Peak Height；以下PHと略)を算出して評価した。

\section{6 . 残存赤血球のLDCLへの影響}

ヘパリン加全血を用い, 遠心して赤血球を得た。赤血 球を, HBSSで 2 回洗浄した後に同液で希釈して, $\mathrm{Hb}$ 量に換算して $0.0 \mathrm{~g} / \mathrm{dl}$ から $1.4 \mathrm{~g} / \mathrm{dl}$ の赤血球浮遊液を作っ た。なお, $\mathrm{Hb}$ 濃度 $0.1 \mathrm{~g} / \mathrm{dl}$ は, 自動血球計数装置で測 定したところ, 赤血球数 $3.80( \pm 0.56) \times 10^{4} \mathrm{cells} / \mu \mathrm{l}$ に 相当していた。この赤血球浮遊液 $50 \mu \mathrm{l}$ を, 好中球浮遊 液 $(\mathrm{Hb}$ 量 $0.1 \mathrm{~g} / \mathrm{dl}$ を含む) $50 \mu \mathrm{l}$ に混和して, 好中球数 3.0 $\times 10^{6} \mathrm{cells} / \mathrm{ml}$ で赤血球混入量 $(\mathrm{Hb}$ 量に換算して) 0.1 $0.8 \mathrm{~g} / \mathrm{d} 1$ の検体を作製した。この 8 段階の赤血球混入好 中球浮遊液を前述の好中球LDCL法で測定し, 残存赤血 球がLDCLに与える影響の検討を行った。

\section{7. 統計的検定方法}

得られた測定值の平均值と標準偏差值を求めた。測定 值間の有意差については, Studentの $\mathrm{t}$ 検定を用い, 危 険率 $5 \%$ 以下を有意とした。また，相関係数の有意性の 検定も，危険率 $5 \%$ 以下を有意とした。

\section{結果}

\section{1. 好中球分離用 capillary tubeの検討}

前述の a ) b ) c ) 及びd）の 4 種類のcapillary tubeを 用いて比較検討した。その結果, 外径が $4 \mathrm{~mm}$ 以下で遠 心器に設定できる長さのtubeを選択すると，1 本の容 量が500 $\mu \mathrm{l}$ 以下となり，LDCLの測定に必要な好中球量 を得るためには， 1 検体当たり 5 本以上のtubeを用い なければならず重層等の操作に時間がかかった。また, tube が太すぎると好中球層を取り出す操作がしにくくなり, かつ収率が低下した。よって，c）の外径 $5 \mathrm{~mm}$ ・肉厚 $0.8 \mathrm{~mm}$ ・長さ $130 \mathrm{~mm}$ のcapillary tube が最も適当と考 えられた。

capillary tubeのシリコンコーティングに関しても検 討したが，プレインの場合と収率の面で有意差がなく， 操作をより簡便にするために，シリコンコーティングは 施さないまを使用することとした。

\section{2. 分離法間の比較}

Table 1に示す各々の分離法を選択し，それぞれにお ける好中球の収率および純度を比較検討した。遠心操作 を加劣ると，Fig.1に示すようにそれぞそれそのtube 内 で上から順に, (1)血墏層, (2)リンパ球・単球層, (3)好中 球層, (4)赤血球層の 4 層に分離できた。従来M-PRMは, 全血と体積比で $1: 1$ の割合で重層して用いられている ${ }^{15,16)}$ が，今回好中球の選択性を上げるために，全血をHBSS で 2 倍希釈して重層した。それにもかかわらずD法では， Fig.1の右端に示すように, リンパ球・単球層が著明に 狭くなっていた。これら4通りの分離法について, Table 2 に好中球の選択性および収率，残存赤血球量を示した。 分離液としてHistopaqueを用いる C 法が，好中球の収 率60.6土11.1\%と最も高值を示し，かつ好中球の選択性 においては $93.1 \pm 4.7 \%$ と従来法である A 法の $94.8 \pm 3.5$ \%とほぼ同等であった。分離液としてM-PRMを用いる D法では，好中球の収率は，従来法より若干高めの 49.3 $\pm 25.3 \%$ となったが，好中球の選択性が $87.8 \pm 7.7 \%$ と 低下しており, かつ溶血操作後の残存赤血球量も, $\mathrm{Hb}$ 濃度に換算して0.8 $1.1 \mathrm{~g} / \mathrm{dl}$ と他の 3 法に比べ有意 $(\mathrm{p}$ <0.001)に高かった。 

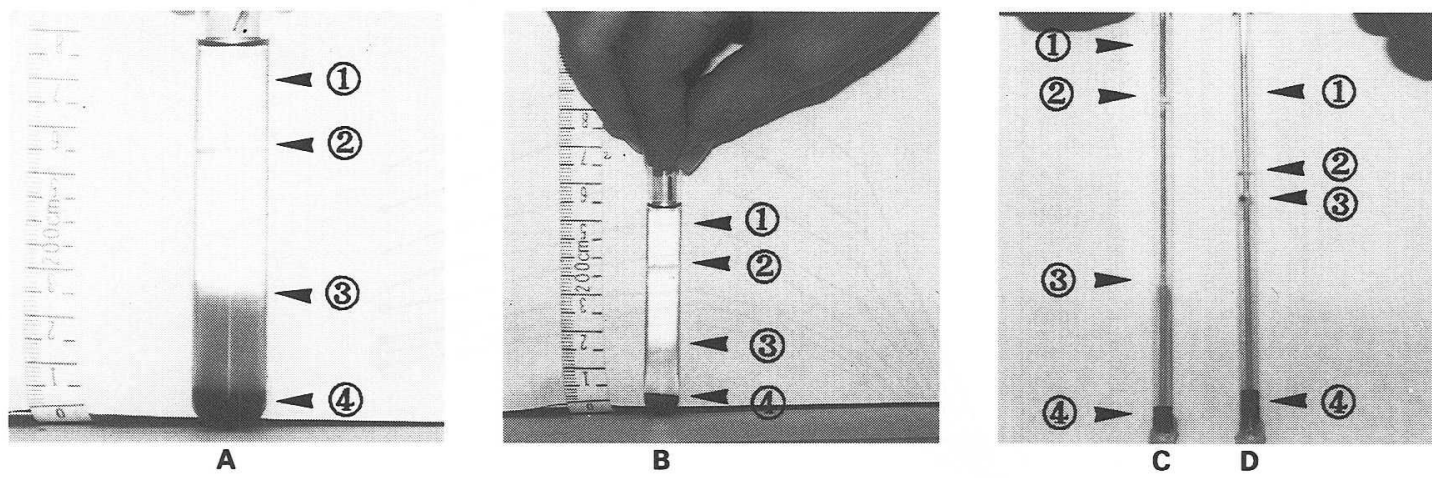

Fig.1 The results from each density gradient method.

Main contents of each fraction are as below.

(1)Top fraction: Plasma (2)Second fraction: Lymphocytes \& Monocytes

(3)Third fraction: Granulocytes (4)Bottome fraction: Erythrocytes

Table 2 Isolation of neutrophils with each density-gradient method

\begin{tabular}{clllllll}
\hline \multirow{2}{*}{ Method } & \multicolumn{5}{c}{ Differential counts (\%) } & \multirow{2}{*}{$\begin{array}{c}\text { Neutrophil yield } \\
(\%)\end{array}$} & $\begin{array}{c}\text { Number of remaining } \\
\text { RBC converted into Hb } \\
\text { concentration }(\mathrm{g} / \mathrm{dl})\end{array}$ \\
\cline { 2 - 7 } & Neutrophils & Eosinophils & Basophils & Lymphocytes & Monocytes & $0.1 \pm 0.0$ \\
\hline A & $94.8 \pm 3.5$ & $2.7 \pm 3.0$ & $0.2 \pm 0.3$ & $2.3 \pm 1.1$ & $0.2 \pm 0.3$ & $29.2 \pm 10.1$ & $0.1 \pm 0.0$ \\
B & $91.7 \pm 5.3^{*}$ & $1.9 \pm 1.3$ & $0.2 \pm 0.6$ & $6.3 \pm 4.8^{*}$ & 0.0 & $27.4 \pm 7.9$ & $0.1 \pm 0.0$ \\
C & $93.1 \pm 4.7$ & $3.1 \pm 2.9$ & 0.0 & $3.2 \pm 1.6$ & 0.0 & $60.6 \pm 11.1^{* * *}$ & $0.1 \pm 0.3$ \\
D & $87.8 \pm 7.7^{* * *}$ & $3.1 \pm 2.9$ & $0.3 \pm 0.5$ & $8.7 \pm 6.3^{*}$ & $0.1 \pm 0.3$ & $49.3 \pm 25.3^{*}$ & $0.8 \pm 1.1^{* * *}$ \\
\hline
\end{tabular}

Each value indicates Mean \pm S.D. $(n=10)$

$*: p<0.05, * *: p<0.01, * * *: p<0.001$; significant difference from method A.

$\mathrm{RBC}$ : red blood cell, $\mathrm{Hb}$ : hemoglobin.

\section{3．LDCLに及ぼす分離法の影響}

$\mathrm{A}, \mathrm{B}, \mathrm{C}, \mathrm{D}$ そそれぞれの分離法で分離した好中球を 用いてLDCLを測定し，PT及びPHを求めた(Table 3)。 ぞの分離法で得られた好中球を用いても，PTには有意 差はなかったが，PHは，D法で分離した好中球を用い た場合，他の 3 法に比べて著明に低下していた。

\section{4. 残存赤血球のLDCLへの影響}

先に述べたように，A法からD法むでの4 通りの方法 で分離した場合の残存赤血球量は， $\mathrm{Hb}$ 量に換算して $\mathrm{A}$ ，

Table 3 Influence of differences among the neutrophil separation methods on chemiluminescent response

\begin{tabular}{ccc}
\hline Method & PT (min) & \multicolumn{1}{c}{ PH $(\mathrm{mV})$} \\
\hline A & $13.1 \pm 1.6$ & $2113.2 \pm 427.7$ \\
B & $14.1 \pm 1.1$ & $2155.7 \pm 460.6$ \\
C & $13.8 \pm 1.6$ & $2010.8 \pm 434.9$ \\
D & $14.5 \pm 2.4$ & $1470.6 \pm 710.5^{*}$ \\
\hline
\end{tabular}

Each value indicates Mean \pm S.D. $(n=10)$

$*: p<0.05$, significant difference from method A. PT: peak time, PH: peak height
B , C 法では0.1g/dlであったのに対して，D法では， $0.8 \mathrm{~g} / \mathrm{dl}$ と 8 倍の高濃度を示していた (Table 2)。この残 存赤血球量の差が，LDCLにおけるPHの差をもたらす 一因と考光，検討した。

残存赤血球濃度を $\mathrm{Hb}$ 換算量で $0.1 \mathrm{~g} / \mathrm{dl}$ から $0.8 \mathrm{~g} / \mathrm{dl}$ の 8 段階に調節した好中球浮遊液を作製し，残存赤血球が LDCLに及ぼす影響を検討した結果をFig.2に示した。 赤血球濃度が濃くなるにつれて, PHが低下したが，PT に対する影響はなかった。健康成人 10 人の好中球を用い て行った結果を, Table 4 に平均値土標準偏差で表示し た。残存赤血球濃度は, 通常行っている溶血操作では, $\mathrm{Hb}$ 濃度に換算して0. $1 \mathrm{~g} / \mathrm{d} 1$ 以下とする事は困難なので，こ の0.1 $\mathrm{g} / \mathrm{dl}$ の濃度を基準として，他の濃度でのPT, PHを \%表示した。残存赤血球濃度が高くなればなるほど $\mathrm{PH}$ （\%)は低下したが，PTには有意差が認められなかった。 さらに, Fig.3に残存赤血球濃度と対数変換したPH $(\%)$ との関係を示した。残存赤血球濃度と\%表示したPHの 対数変換值の間には, 有意の負の相関 $(r=-0.99$, $\mathrm{P}<0.001)$ が認められた。 


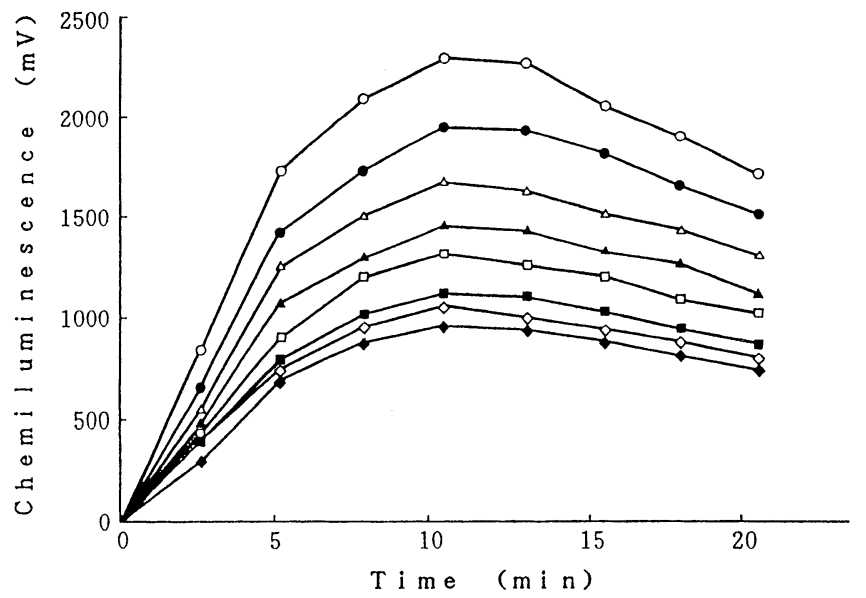

Fig.2 Effect of remaining $\mathrm{RBC}$ on the luminol-dependent chemiluminescence response when stimulated by opsonized zymosan.

The number of remaining $\mathrm{RBC}$ converted into hemoglobin concentration . Hemoglobin concentrations were $0.1(\bigcirc), 0.2(\bigcirc), 0.3(\triangle), 0.4(\mathbf{\Delta})$, $0.5(\square), 0.6(\square), 0.7(\diamond)$ and $0.8(\diamond) \mathrm{g} / \mathrm{dl}$.

Table 4 Effect of remaining $\mathrm{RBC}$ on Luminol-dependent chemiluminescence

\begin{tabular}{crrrr}
\hline \multirow{2}{*}{$\begin{array}{c}\text { concentration of remaining RBC } \\
\text { (converted into } \mathrm{Hb}(\mathrm{g} / \mathrm{dl}))\end{array}$} & \multicolumn{4}{c}{ LDCL } \\
\cline { 2 - 5 }$(\mathrm{min})$ & \multicolumn{1}{c}{$\mathrm{PT}(\%)$} & $\mathrm{PH}(\mathrm{mV})$ & PH $(\%)$ \\
\hline 0.1 & $13.6 \pm 2.8$ & $100.0 \pm 0.0$ & $2169.9 \pm 573.1$ & $100.0 \pm 0.0$ \\
0.2 & $13.6 \pm 2.3$ & $100.9 \pm 3.5$ & $1823.5 \pm 494.9$ & $84.1 \pm 7.3$ \\
0.3 & $13.7 \pm 2.6$ & $101.1 \pm 3.1$ & $1539.2 \pm 442.6$ & $70.9 \pm 6.5$ \\
0.4 & $13.4 \pm 2.1$ & $99.6 \pm 6.6$ & $1372.3 \pm 371.9$ & $63.3 \pm 5.4$ \\
0.5 & $13.8 \pm 2.3$ & $101.5 \pm 4.5$ & $1189.4 \pm 318.2$ & $55.1 \pm 6.0$ \\
0.6 & $12.3 \pm 0.9$ & $98.9 \pm 4.6$ & $1252.9 \pm 207.1$ & $51.3 \pm 6.3$ \\
0.7 & $12.1 \pm 1.3$ & $98.5 \pm 7.7$ & $1125.5 \pm 99.4$ & $45.4 \pm 4.4$ \\
0.8 & $12.3 \pm 0.9$ & $98.3 \pm 8.7$ & $1048.1 \pm 118.0$ & $43.5 \pm 4.9$ \\
\hline
\end{tabular}

Each value indicates Mean \pm S.D. $(n=10)$

$\mathrm{Hb} 0.1 \mathrm{~g} / \mathrm{dl}$ is equivalent to $\mathrm{RBC} 3.80( \pm 0.56) \times 10^{4} \mathrm{cells} / \mu \mathrm{l}$.

\section{考察}

CL法は, 1972年Allen ら ${ }^{1)}$ が報告して以来, 様々な改 良が加えられ，その再現性の良さや簡便性から，好中球 機能を検討する際に広く活用されてきた。現在では，各 種の増感剤を用いることにより, 好中球より発生する活

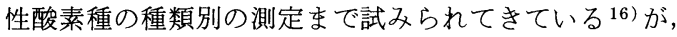
1 回の測定には $1 \times 10^{6} \mathrm{cells} / \mathrm{ml}$ 以上の好中球数を必要 とする。デキストラン法よりも収率が良くかつ操作も簡 便迅速なHistopaqueを用いる比重勾配法6)で好中球を 分離し，LDCLの測定を行うためには，最低でも $4 \mathrm{ml}$ 以上の採血量を要した。したがって, 集団健診等におけ るスクリーニング検査や新生児等の採血量に制限のある
検体を対象として，CL法で好中球の機能を検討するの は困難であった。

1988年にThomas $5^{18)}$ は，遠心操作により好中球に 富むbuffy coatを取り出してLDCLを行い，新生児期の 好中球機能を論じているが， buffy coatの構成細胞分画 を明確にしていない。また，細胞数をそろえずにLDCL を測定し，好中球数と PHが正比例関係にあるものとし て，好中球数1000個当たりの発光量に換算して報告して いる。他にも好中球を単離せずに全血のまをでCLを測 定し, 単位好中球当りの発光量に換算した報告はある ${ }^{19,20)}$ が，それぞれ測定結果がまちまちであり，好中球を単離 せずに全血のままで測定し，単位好中球当りで表してい る点に問題があると考えられた。 


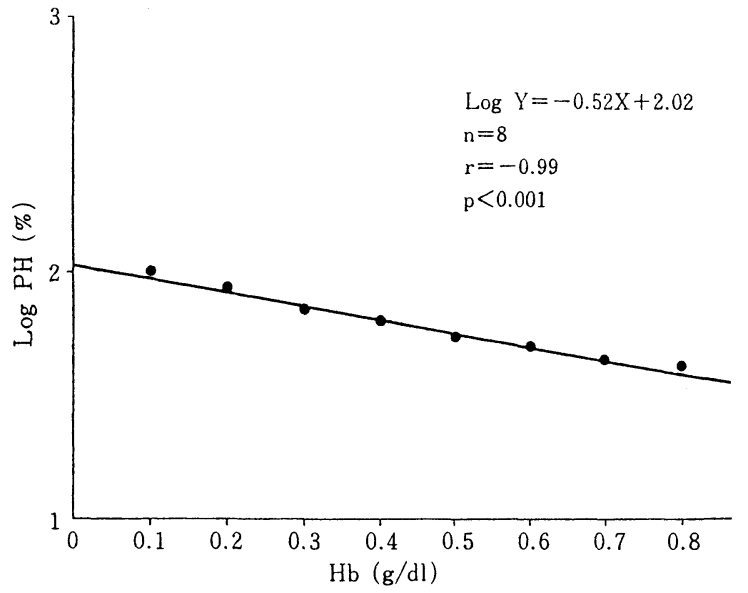

Fig.3 Relationship between remaining RBC and peak height of the luminoldependent chemiluminescence.

The number of remaining $\mathrm{RBC}$ converted into hemoglobin concentration .

The percentage of peak height was converted into a common logarithm .

$\mathrm{Hb}$ : Hemoglobin, $\mathrm{PH}$ : Peak height.

今回の少量採血による好中球分離法を検討した結果で は, $500 \mu \mathrm{l}$ の採血量で好中球を高収率高純度で単離する には, 外径 $5 \mathrm{~mm}$ ・肉厚 $0.8 \mathrm{~mm}$ ・長さ $130 \mathrm{~mm}$ のcapillary tubeが最も適していた。

分離液として今回我々は，Histopaque とM-PRMを 使用してみた。M-PRMは，比重1.114 Ficoll-Hypaque 混合溶液で, 重層の手間なく好中球を単離できる利点が ある15,16)が，実際使用してみたところリンパ球・単球 層が狭く，好中球層にリンパ球の混入が多かった。また 赤血球が好中球層に混入する率がHistopaque を重層し た場合より高かった。Histopaque-1077および1119の重 層法は, 重層の手間が 1 回多いが好中球の分離状況から みると有用であると考えられる。また，M-PRMを用い て好中球を単離した場合はLDCLでPHの低下が認めら れた。溶血操作後も残存する赤血球およびHbが，CLの 妨げになることが論じられており 5, 20,21)，好中球分画に 赤血球の残存が多いことが，D法で分離した好中球を用 いてLDCLを測定した場合のPHの低下をもたらす一因 と考えられた。そこで, 残存赤血球がLDCLに及ぼす影 響について検討してみた。Fig.2およびTable 4 に示す ように, 残存赤血球濃度が高くなるほどPHは低下する が，PTには影響は認められなかった。このPHの低下を 引き起こす原因として，Hbの色素による色クエンチン グ作用 ${ }^{21)}$ が考㝋られる。また，好中球に superoxide dismutase (SOD)を添加した場合にも，今回の結果と同 様にPTにはほとんど影響が認められずPHのみが低下す
る17)ことから, 赤血球中に存在する $\mathrm{SOD}^{22)}$ が, 活性酸 素種を除去する方向に働くことも推測できる。残存赤血 球量とPHとの間に認められた高い負の相関関係をもと に, D法より分離した好中球のPH值を, Fig.3の直線 回帰式を用いて補正してみたところ $2180.5 \pm 378.7 \mathrm{mV}$ となり， A 法でのPHと近似した值となった。したがっ て，このことからも残存赤血球が，PHの低下をもたら す原因となっていたものと考学られた。

以上より $500 \mu \mathrm{l}$ の少量採血量でも，LDCL測定に十分 な好中球を分離できる方法が確立された。今後, 感染症 が重篤化しやすい新生児期の免疫機能検査や集団健診等 のスクリーニング検査の一項目として, この好中球分離 法を用いた好中球機能の検討が活用できるものと思われ る。

\section{結語}

LDCL測定を500 $\mu \mathrm{l}$ という少量採血量で行うために， 好中球を高純度高収率で分離する方法を検討し，以下の 結果を得た。

1. 重層に用いるtubeの規格を検討した結果, 外径 $5 \mathrm{~mm}$ - 肉厚 $0.8 \mathrm{~mm}$ ・長さ $130 \mathrm{~mm}$ のcapillary tubeが, 遠 心等の操作が可能で, 取扱いやすく, 収率の面でもす ぐれていた。

2. 分離液としては，M-PRMよりもHistopaque-1077 と1119を重層して用いたほらが，好中球の選択性の面 で優れていた。 
3. 好中球分画中に残存する赤血球量と, LDCLのPH の間には高い負の相関関係が認められた。したがって, 好中球分画中の残存赤血球量はなるべく少なくするこ とが望ましいと考えられる。

\section{文献}

1 ) Allen, R.C., Stjernholm, R.L. and Steele, R.H.: Evidence for the generation of an electronic excitation state(s) in human polymorphonuclear leukocytes and its participation in bactericidal activity, Biochem. Biophys. Res. Commun., 47, 679-684 (1972).

2 ) Allen, R.C. and Loose, L.D.: Phagocytic activity of a luminol-dependent chemiluminescence in rabbit aeveolar and peritoneal macrophages, Biochem. Biophys.Res. Commun., 69, 245-252 (1976).

3 ) Allen, R.C.: Evaluation of serum opsonic capacity by quantitating the initial chemiluminescent response from phagocitizing polymorphonuclear leukocytes, Infect. Immun., 15, 828-833 (1977).

4 ) Wilson, M.E., Trush, M.A., van Dyke, K., Kyle, M.J., Mullet, M.D. and Neal, W.A.: Luminoldependent chemiluminescence analysis of opsonophagocytic dysfunctions, J. Immunol. Meth., 23, 315-326 (1978).

5 ) Andersen, B.R. and Brendzel, A.M.: Use of a unique chemiluminescence spectrometer in a study of factors influencing granulocyte light emission, J. Immunol. Meth., 19, 279-287 (1978).

6 ）熊江 隆，菅原和夫：好中球Chemiluminescence $の$ 多検体同時測定法, 日血会誌，50，949-957 (1987).

7 ) 佐分利能生, 熊江 隆, 那須 勝, 系賀 敬, 長門 宏：珪肺患者における好中球Chemiluminescenceの 検討，日胸疾患会誌，27，57-63 (1989).

8 ) Kumae, T., Saburi, Y., Nasu, M., Misumi, J. and Kawata, N. : Effects of cefbuperazone on the chemiluminescence of human neutrophils, Chemotherapy , 35, 260-266 (1989).

9 ) Osanai, T., Shiroto, C. , Mikami, Y., Kudoh, E. , Komatsu, T., Nakaji, S., Kumae, T., Sugawara, K. and Sasaki, M.: Measurement of GaALAs diode laser action on phagocytic activity of human neutrophils as a possible therapeutic dosimetry determinant, Laser Ther. , 2, 123-133 (1990).

10) Quie, P.G.: In "Nelson textbook of pediatrics, 13 edition" (Editor: Nelson, W.E.), p.476, W.B. Saunders Company, Philadelphia and Tokyo (1987).

11) Wright, W.C., Ank, B.J., Herbert, J. and Stiehm, E.R. : Decreased bactericidal activity of leukocytes of stressed newborn infants, Pediatrics, 56, 579-584 (1975).

12) Mills, E.L., Thompson, T., Bjorksten, B., Filipovich, B.S. and Quie, P.G. : The chemiluminescence response and bactericidal activity of poly morphonuclear neutrophils from newborns and their mothers, Pediatrics, 63, 429-434 (1979).

13) Boyum, A.: Separation of leukocytes from blood and bone marrow, Scand. J. Clin. Lab. Invest., 21, suppl. 97, 9-109 (1968).

14) English, D. and Andersen, B.R.: Single-step separation of red blood cells, Granulocytes and mononuclear leukocy tes on discontinuous density gradient of ficoll-hypaque, J. Immunol. Meth., 5, 249-252 (1974) .

15) Ferrante, A. and Thong, Y.H.: A rapid one-step procedure for purification of mononuclear and polymorphonuclear leucocytes from human blood using a modification of the hypaque-ficoll technique, J. Immunol. Meth., 24, 389-393 (1978).

16) Needham, P.L.: The separation of human blood using mono-poly resolving medium, J. Immunol. Meth., 99, 283-284 (1986).

17）小松 尚, 工藤恵美子, 中路重之, 熊江 隆, 菅原 和夫 : Luminol-dependent Chemiluminescence $に$ よる好中球産生活性種酸素の測定, 弘前医学, 43, 328-337 (1992).

18) Thomas, V.L, Sanford, B.A., Driscoll, M.S.,Casto, D.T. and Ramamurthy, R.S. : Luminol-dependent chemiluminescence microassay for phagocytic function, J. Immunol. Meth., 111, 227-232 (1988).

19）松木隆任, 上野範博, 大川正人, 鹿野高明, 外岡 立, 松本脩三：全血利用luminol 依存性Chemiluminescence, 日臨免疫誌, 6, 195-203 (1983).

20) Tonooka, T., Ueno, N., Ohkawa, M. and Matsumoto, S. : Chemiluminescence of whole blood. 1. A simple and rapid method for the estimation of phagocytic function of granulocytes and opsonic activity in whole blood, Clin. Immunol. Immunopathol., 26, 66-75 (1983). 
21）佐倉伸夫, 小林陽之助, 臼井朋包 : 白血球殺菌能試 験一Chemiluminescence, 細胞性免疫機能検査のす べて(月刊Medical Technology 編)，p.31，医歯薬 出版, 東京 (1985).
22) Hartz, J.W. and Deutsch, H.F.: Subunit structure of human superoxide dismutase, J. Biol. Chem., 247, 7043-7050 (1972).

（受付 1991 年 9 月 10 日 受理 1991 年12月18日） 